\title{
Bumdes Acceleration Towards Mandiri Village
}

\author{
Khairul Amri \\ Public Administration Study Program, Fakultas Ilmu Sosial dan Ilmu Politik, Universitas Riau \\ (email: khairul.amri@lecturer.unri.ac.id)
}

\begin{abstract}
Village-owned enterprises (BUMDES) are village business institutions that are managed by the community and village government in an effort to strengthen the village economy and be formed based on the needs and potential of the village. In fact there are some villages that have succeeded in running and developing BUMDes, but there are still many BUMDES that are stagnant and even unproductive in Indonesia. The purpose of this study is to determine the conditions and governance of BUMDes that are successful and growing. The method used is a qualitative approach, this type of research uses literature studies by looking for theoretical references relevant to the case or problem found. The results of this study indicate that the Empowerment of Village Communities by the government through the Village Owned Enterprises (BUMDes) program is an appropriate and relevant effort to Indonesia which is geographically very broad and has diverse potential in each region and village. BUMDes can be the main wheel of economic drivers in the village. But, the acceleration is still not optimal, if seen from the number of BUMDes that succeed with the Number of Villages in Indonesia, it needs to be a common concern in order to improve and achieve goals
\end{abstract}

\section{Keywords:}

acceleration; BUMDES; desa mandiri

\section{Introduction}

Indonesia is a big country and has lofty ideals to create justice and prosperity for all its people. This is stated in the opening of the 1945 constitution in the IV-alenia, which is to create welfare in a just and prosperous manner. To be able to realize these ideals, the government needs to carry out national development in the community empowerment sector to all corners to villages in this country.

The development process in rural areas already has a legal umbrella as stipulated in Law No. 6 of 2014 concerning Villages, then also stipulated in Law (Law) Number 23 of 2014 concerning Regional Governments in Article 213 Paragraph (1) states that "Villages can establish Village-Owned Enterprises in accordance with the needs and potential of the village ". The substance of this law emphasizes the promise of meeting demand (demand 
complience scenario) in the context of development and community empowerment at the village level.

Decentralization has continued to develop since the era of regional autonomy and continues to provide significant changes in the implementation of community development by the government. Local governments are given the authority to be able to carry out development in the regions ... this is what has an impact on the current administration of local governments to become more independent and have the potential to carry out development in accordance with the potential needs of the region. Indonesia itself is very broad and has diverse natural resources and is an archipelagic country which in reality is not optimal if development is only carried out by the central government.

Data from the Indonesian Central Statistics Agency in Noerma Alifahrani Bahtiar in 2017, The role of the village is very important because most of the Indonesian population live in rural areas. Especially outside Java because its territory is still in the form of a traditional village and its inhabitants depend heavily on nature such as farming, gardening, raising livestock and others. The total population of Indonesia in 2010 was 237,641,326 people, including those who lived in urban areas as many as 118320256 people (49.79 percent) and in rural areas as many as 119321070 people (50.21 percent).

The Ministry of Villages, Disadvantaged Regions and Transmigration (Kemendes PDTT) noted that as of December 2018, 61 percent of villages had village-owned enterprises (BUMDes), or 45,549 BUMDes units had been formed in Indonesia. This number increased sharply from 2014 which only had 1,022 BUMDes. This means that the quantity has increased sharply, but the quality needs to be considered so that the expected village development is realized properly.

The portrait of life in the village which has been identical with backwardness has often been raised to the public surface but until now there has not been a concrete solution from the government that is able to improve life in the village (source: Statistics Indonesia, 2016 through: (www.bps .go.id). While the large population of Indonesians living in villages has the potential to determine the overall success of development.

Village-owned enterprises (BUMDES) are village business institutions that are managed by the community and village government in an effort to strengthen the village economy and are formed based on the needs and potential of the village. Village-owned 
enterprises (BUMDes) according to Law No. 32 of 2004 concerning regional government were established, among others, in the context of increasing Village Original Revenue (PADes) and towards Independent Village. So BUMDes has the same status as companies that can manage businesses in accordance with the potential of each village.

Solekhan (2014: 73) in Valentine queen Chintary and Asih Widi Lestari, Noting the large role of Village-Owned Enterprises (BUMDes) in providing alternatives to several mentoring and grant programs, it is necessary to have a good management concept including: (1) management of BUMDes must openly, and can be known by the public. (2) BUMDes management must be accountable to the village community by following the rules and regulations in force. (3) the village community is actively involved in the planning, implementation and supervision processes. (4) and the management of BUMDes must provide results and benefits for citizens in a sustainable manner.

Therefore, in terms of contributing to the PADes for the creation of an Independent Village, the BUMDes must have a good management concept. The purpose of this study is to determine the conditions and governance of BUMDes that are successful and growing. Therefore, the development of rural communities should be very important to note, in this case the Village-Owned Enterprises (BUMDes) so that the distribution of development in Indonesia can be realized optimally.

\section{Theoretical Framework}

Village-owned Enterprise (BUMDes) is a community-owned business entity and village government that is engaged in the economy. In its implementation it also has a variety of both potential complexity and challenges in each village. Some are running well and even experts (exceeding the target set), some are running stagnant (walking on the spot) and even losing a not small amount. Departing from the above, the writer then tries to remind again the importance of Village Community Development, in this case the BUMDes Program in realizing equitable development to the remote villages in Indonesia.

Various theories, concepts and opinions of the authors present to remind the various potentials and challenges as well as the things that influence in the implementation of rural community development in this case the Village Owned Enterprises (BUMDes) program. The author uses this type of literature study research by looking for theoretical 
references relevant to the case or problem found. The theoretical references obtained by means of research literature studies serve as a basic foundation and main tool for discussing various issues related to Village-Owned Enterprises (BUMDes). The theory or concept used is related to the field of scientific administration and public policy.

\section{BUMDES and Village Government}

Village government is an extension institution of the central government that owns it a strategic role in the regulation of rural / urban communities and the success of national development (Rafsanzani, et.al., 2010). Because, the village government has a significant role in managing social processes in the community. The main task carried by the village government is how to create democratic life, provide good social services so that it can bring its citizens to a prosperous, peaceful, and just life. In order to realize this task, the village government is required to make changes in a "radical" manner, both in terms of leadership and the performance of the bureaucracy which is oriented towards village services, so that it really leads to better governance practices, not bad governance (Dwipayana and Eko, 2003 ).

Furthermore Dwipayana and Eko (2003) explained that if the concept of good governance is placed within the scope of the village then there are two strategic issues that are important to consider. First, the issue of democratic governance (democratic governance), namely the village government that comes from community participation, is managed with accountability and transparency by the community, and then utilized as well as possible for the responsiveness of the community itself. Second, the relationship between governance elements in the village is based on the principle of alignment, balance, and trust in carrying out village development collectively to achieve the common good.

The village government becomes the center of village governance that has relations with the BPD, elements of civil society, and the economic community. The position of the village head is as personification of the village government. The village government and the village head are part of the chain of the state bureaucracy that carries out the regulatory and control functions in the region through administrative services, implementation of development projects, community mobilization to support government policies in providing services to citizens in the village (Fajar Sidiq 2015). 
Meanwhile, according to Sunartiningsih in (Fajar Sidiq 2015) village empowerment in the context of village communities is the ability of individuals who are united in the community and building the empowerment of the community concerned. A society where most of its members are physically and mentally healthy, educated and strong, certainly has a high level of empowerment. However, in addition to physical things like that also develops intrinsic values such as family values, mutual cooperation, and diversity. The empowerment then becomes the basic element that enables a community to survive and in a dynamic sense develop themselves in achieving their goals. Community empowerment emphasizes more on efforts to improve the dignity and levels of the people who in their present condition cannot escape the pitfalls of poverty and underdevelopment.

In other words, empowering people is the same as enabling and independence of the community. Widjaja (2011) has explained that the core of empowerment is an effort to awaken all the village's abilities to achieve the goal. Achievement of goals is done through the growth of motivation, initiative and creativity to advance the economy and bring prosperity to the village.

Furthermore Fajar Sidiq 2015 explained that one of the important instruments in realizing an independent village was to establish a BUMDes. BUMDes can be used as a place for local residents to empower and independence the village from the tourist village destinations that have been offered. Because the village is seen as a legal community unit or public legal entity also has authority even though it is not as extensive as the authority held by the regional government. Village authority is the village's right to regulate, administer and be responsible for government affairs and the interests of the local community; what is meant by "regulating" and "managing" and what is meant by "governmental affairs" and "the interests of the local community".

Eko in (Fajar Sidiq 2015) explained regulating and taking care of it in several meanings, namely: (1) issuing and implementing rules of the game (rules), about what is permissible or not, so that it is binding on the parties concerned; (2) responsible for planning, budgeting for funds and carrying out development or service activities, and solving problems that arise; (3) decides and runs the allocation of resources (both funds, equipment and personnel) in development activities or services, including sharing resources with beneficiaries; and (4) taking care means running, implementing, and maintaining the 
regulated public goods. Implementation of development and public service is a concrete form.

In Law No. 6 of 2014 concerning Villages, BUMDes is a business entity that in whole or most of its capital is owned by the village through direct participation from village assets that are separated to manage assets, services, and other businesses, as much as $\neg$ the largest for welfare villagers. The BUMDes exists to increase income and villages in accordance with the needs and potential of the village (PP No 72/2005, Article 78 Paragraph 1). In its implementation, the regency / city government stipulates regional regulations (Perda) regarding guidelines for the formation and management of BUMDes. This provision is mandatory, not voluntary so that the management of BUMDes is in accordance with the characteristics of each region (Permendagri No 38/2010 concerning BUMDes).

Then, in Article 87 paragraph (1) in the Village Law it is explained that the village can establish a Village Owned Enterprise called BUM Desa; BUM Desa is managed with a family spirit and mutual cooperation (paragraph 2); and (paragraph 3) BUM Desa can run businesses in the economy and / or public services in accordance with statutory provisions. The word "can" in the Act implies that villages are given the opportunity, rights and authority to establish BUMDes.

Therefore, Sutopo (in Hastowiyono and Suharyanto, 2014) explained that BUMDes is a village business institution that is managed by the community and village government in an effort to strengthen the village economy and is formed based on community needs and village potential. BUMDes is a form of village institution that has the activity of running an economic or business venture to obtain benefits that are useful for the welfare of the village community. Furthermore, Sutopo emphasized that the Village established BUMDes was not solely to seek economic benefits or profits, but also included social benefits and other non-economic benefits.

Agung yusuf agunggunanto et al (2016) explained that BUMDes consists of business units with legal entities in which BUMDes share ownership is obtained from the village government and the community. BUMDes management is separate from management in the Village Government organization. The BUMDes management structure consists of advisors, operational implementers and supervisors. The BUMDes advisor is held by the village head / village head or village official. Advisers have the obligation, 
among others, to provide advice on the implementation of BUMDes management to operational operators, provide advice and opinions on issues that are considered important in the management of BUMDes and control the implementation of activities in BUMDes management. BUMDes needs competent people to carry out BUMDes operations professionally.

Furthermore Agung Yusuf Agunggunanto et al (2016) explained the recruitment of managers of BUMDes, especially for managerial positions, at least having experience in institutions that have a orientation to the profitability of business activities. Educational background is also important for BUMDes managers to be able to carry out their duties and functions in accordance with their work. Obligations of operational implementers according to those listed in Law No. 4 of 2015, namely implementing and developing BUMDes in order to become an institution that serves the economic needs and public services of rural communities, explore and exploit the potential of village economic efforts to increase the village's original income and collaborate with other village economic institutions.

So the BUMDes Institution is a separate institution from the Village Government Institution, BUMDes has its own structure and only needs coordination with the village government. The recruitment process, especially for managerial positions, is also more professional by taking into account experience, educational background in order to be able to optimally develop BUMDes in assisting village governments in the development of the economic sector of society.

Institutional definitions can be divided into two classifications (Erani in Edy Yusuf Agunggunanto 2016). Institutional when viewed from the process is an attempt to design patterns of interaction between economic actors in order to carry out transaction activities. Institutional aims to create economic efficiency based on political and social relations between actors and structures of economic power. BUMDes as a new institution at the village level has opportunities and challenges. Therefore, the governance or management of BUMDes must be arranged so that they are able to compete and assist the community in improving their economy. Good institutions have principles or rules that support the running of the organization and there are occupations that are covered that are described by the organizational structure of the establishment of BUMDes need to balance the 
strengthening of governance and regulatory rules. A weak legal basis can make BUMDes vulnerable to conflict.

This is reinforced by the concept of performance (Performance) can be defined as an achievement of the results or degree of accomplishment (Rue and byars, 1981 in Keban 1995). So, the performance of an organization can be seen from the degree to which the organization can achieve its goals based on predetermined goals. Performance is the result of collaborative activities among members or components of the organization in order to realize organizational goals.

While the organization is a form of human union to achieve a common goal. But we need to understand that the basis of the organization is not "who" but "what" which means that it is not the person who will hold the organization, but the "what" task from the organization. (Money, 1996: 23)

\section{BUMDES and Village Potential Development}

In Mahbub Junaidi 2015 states that BUMDes management principles are important to be elaborated or elaborated so that they are understood and perceived in a way that same by the village government, members (accompanying capital), BPD, Regency Government, and the community. There are 6 (six) principles in managing BUMDes, namely: First, Cooperative, All components involved in BUMDes must be able to conduct good cooperation for the development and survival of their businesses; Second, Participatory. All components involved in BUMDes must be willing to volunteer or be asked to provide support and contributions that can drive the progress of BUMDes businesses; Third is Emancipative. All components involved in BUMDes must be treated equally regardless of class, ethnicity, and religion; Fourth Transparent. Activities that affect the interests of the general public must be known to all levels of society easily and openly; Fifth Accountable. All business activities must be technically and administratively accountable; Sixth Sustainability. Business activities must be able to be developed and conserved by the community in the BUMDes container.

Further Mahbub Junaidi 2015 explained Related to the implementation of the Village Fund Allocation (ADD), the process of strengthening the village economy through BUMDes is expected to be more empowered. This is due to the support of funds village 
budget that is getting bigger. To enable the availability of sufficient capital to establish BUMDes. If this goes hand in hand, there will be an increase in the PADesa, which can then be used for village development activities.

The main thing that is important in efforts to strengthen the village economy is to strengthen cooperation (cooperatives), build togetherness / establish cohesion in all levels of village society. So that it becomes a driving force (steam engine) in an effort to alleviate poverty, unemployment, and open market access. more empowered. This is due to the existence of a supporter namely increasing village budget funds. To enable the availability of sufficient capital for the development of BUMDes. If this goes hand in hand, there will be an increase in the PADesa, which can then be used for village development activities. The main thing that is important in efforts to strengthen the village economy is to strengthen cooperation (cooperatives), build togetherness / establish cohesion in all levels of village society. So that it becomes a driving force (steam engine) in an effort poverty alleviation, unemployment, and open market access.

\section{BUMDES in Realizing Mandiri Village}

Budiono (2015) explained that one way to encourage development at the village level is that the village government is given authority by the central government to independently manage the scope of the village through economic institutions at the village level. One of these institutions is the Village-Owned Enterprises (BUMDes).

Then Edy Yusuf Agunggunanto (2016) explained the main characteristics of BUMDes that distinguish other commercial institutions (PKDSP, 2007) are (1) Business entities are village-owned and their management is carried out jointly; (2) Business capital of $51 \%$ comes from village funds and $49 \%$ comes from community funds; (3) The operationalization is based on a local culture-based business philosophy; (4) The potential of the village and the results of available market information are the basis for running the business sector; (5) Earnings obtained by BUMDes are used for efforts to improve the welfare of members and the community based on the rules that have been prepared; (6) Facilities supported by Provincial, Regency and Village Governments; and (7) The implementation of BUMDes operational is jointly supervised by the Village Government, BPD and members. 
So BUMDes is an autonomous business entity, absolute ownership is in the hands of the Village through the Community and Village Government, beyond that no one may invest in BUMDes itself. So that with this authority BUMDes can manage the potential in the village to the maximum, strengthened with the village government which has the largest share, of course it can support with breakthroughs and with policies. This is also supported by Hardijono et al (2014) that the establishment of BUDes is a way to establish an independent rural economy in an effort to increase Village Original Income.

Furthermore Edy Yusuf Agunggunanto (2016) explained, an independent village is a village that is able to meet their needs and if there is assistance from the Government, the assistance is only stimulatory. Independent village development includes development planning activities that are participatory, transparent, accountable and detailed. These activities go through a series of stages namely planning and preparation, general village identification, village asset analysis and village development planning meetings (musrenbangdes).

This is consistent with Law No. 32 of 2004 the definition of village is regulated in Article 1 paragraph (12) as follows "Village or referred to by another name, hereinafter referred to as village, is a legal community unit that has territorial boundaries authorized to regulate and manage the interests of the local community, based on origin local customs and customs that are recognized and respected in the Government of the Unitary Republic of Indonesia system. " The definition of village described in Article 1 paragraph (1) of Law Number 6 of 2014 explains "Village is a village and a customary village or referred to by another name, hereinafter referred to as Village, is a legal community unit that has the authority to regulate and manage affairs governance, interests local community based on community initiatives, original rights, and / or traditional rights that are recognized and respected in the system of government of the Unitary Republic of Indonesia ".

Based on information from the BERDESA.COM Website, about the 5 best BUMDes in Java.

1. BUMDes Karangkandri Sejahtera

Karangkandri Village, Cilacap Kesugihan District utilizes the existence of a Steam Power Plant as a business opportunity. The village then established the BUMDes with a supplier business unit for various needs for PLTU. BUMDes Karangkandri Sejahtera 
supplies bolder needed by PLTU. As a result, the funds that have entered BUMDes reached Rp. 7 billion. Not included in the bill which reached Rp. 5 billion.

2. BUMDes Tirta Mandiri

His photos are widespread on social media and Google. That is the tourist attraction of Ponggok, Ponggok Village, District of Polan, Klaten. A natural swimming pool that has a myriad of unique attractions for its visitors. The visitors can take pictures of themselves in the water with all kinds of activities such as posing on a motorcycle, even sitting while facing a laptop.

The coolness of natural water with the bottom of the pond that is left natural makes this pool into an extraordinary underwater garden. This charm is what draws thousands of visitors to come there every day. As a result, Rp. 6 billion recorded every year by this tourist attraction. That's just from the side of the tour. Ponggok also develops freshwater aquaculture and is a fisheries-based culinary center which also attracts visitors from outside the area.

3. BUMDes Srisadani, Kedungprimen, Bojonegoro

It is a tradition for farmers in the Bojonegoro Regency and surrounding areas, to run their farm they suck water from the legendary Bengawan Solo. The large water demand for agriculture makes irrigation costs for rice fields a separate business cycle. This is what Srisadani is aiming for.

BUMDes srisadani develops the pumping business of tero rental in agriculture and earns Rp. 1.3 billion per year.

4. BUMDesa Tirtonirmolo

This BUMDes, owned by the residents of Kasihan Village, Bantul, is developing a savings and loan business unit. Departed in 1990 with a capital of Rp. 1 million and additional capital of Rp. 10 million, now this savings and loan has printed a turnover of Rp. 8.7 billion.

It is not only savings and loans that are gigantic, the existence of the village banking system has also led to the creation of economic improvement among MSME actors in the village. Savings and loans Tirtonirmolo proves itself able to push a variety of potential villages into income residents.

5. BUMDes Sejahtera Bleberan 
In just a few years the Sri Getuk waterfall in Bleberan Village, Gunungkidul, Yogyakarta, became a tourist attraction that attracted extraordinary visits. Like a meteor, Sri Getuk sped into a tourist attraction that brought in Rp. 2 billion a year. Not only that, the number of tourist visits also encourage many new businesses to grow and develop among the people.

Those are the five best BUMDes in Java. The villages, with their various potentials, So, to create an independent village with BUMDes is not impossible, but can be realized as long as there is seriousness from the village government as BUMDES advisor and community motivator, then preparing qualified human resources and organizations and the community participatory one. The BUMDes above succeeded in creating an independent village with a turnover that was not small for the size of the village. The success of the BUMDes above needs to be transformed to all other BUMDes throughout Indonesia, because the success of forming an Independent Village is very instrumental in supporting national development.

This is strengthened in Surjadi 2009: 7, Organizational performance is the totality of the work achieved by an organization achieving organizational goals means that, the performance of an organization can be seen from the degree to which the organization can achieve goals based on the goals set previously.

\section{Conclusion}

Village Community Empowerment by the government through Village-Owned Enterprises (BUMDes) is an appropriate and relevant effort to Indonesia that is geographically very broad and has diverse potential in each region and village. BUMDes is a separate institution from the village government agency, and is engaged in profit-oriented economics. BUMDes can be the main wheel of economic drivers in the village.

BUMDES in creating an Independent Village in Indonesia has not been implemented to the maximum. This can be seen from only a small portion of BUMDES who successfully carry out their functions of creating independent villages, and most are still stagnant and even lose money. Because of this there needs to be an acceleration from the government by transforming the success of BUMDes that have succeeded to all other BUMDes throughout Indonesia. 
This needs to be supported and developed in a sustainable manner. Although it is still not optimal when seen from the number of BUMDes that succeed with the Number of Villages in Indonesia, it needs to be a joint concern in order to improve and achieve goals. The spirit transformation by the government related to BUMDes-BUMDes that has been successful to BUMDes that are still stagnant throughout Indonesia needs to be more intensive so that the acceleration of BUMDes to independent villages can be realized and become a potential energy in efforts to accelerate national development.

\section{References}

Ade Eka Kurniawan 2015, Peranan Badan Usaha Milik Desa (BUMDES) Dalan Peningkatan Pendapatan Asli Desa (Desa Lanjut Kecamatan Singkep Pesisir Kabupaten Lingga Tahun 2015), Tanjungpinang: Universitas Maritim Raja Ali Haji

Dendhi Agung Nugroho 2015, Evaluasi Penerapan dan Dampak Program Badan Usaha Milik Desa (BUMDES) Terhadap Kesejahteraan Masyarakat Rumah Tangga Miskin (RTM) di Desa Babadan Kecamatan Karangrejo Kabupaten Tulungagung (Periode Mei 2014-April 2015), Malang: JESP

Dwi Pratiwi Kurniawati, Bambang Supriyono dan Imam Hanafi 2013, Pemberdayaan Masyarakat di Bidang Usaha Ekonomi (Studi pada Badan Pemberdayaan Masyarakat Kota Mojokerto), Malang: Jurnal Administrasi Publik (JAP)

Edy Yusuf Agunggunanto dkk 2016, Pengembangan Desa Mandiri Melalui Pengelolalaan Badan Usaha Milik (BUMDes), Jepara: Jurnal Dinamika Ekonomi dan Bisnis (JDEB) Fajar Sidik 2015, Menggali Potensi Lokal Mewujudkan Kemandirian Desa, Yogyakarta: JKAP

Irfan Nursetiawan 2018, Strategi Pengembangan Desa Mandiri Melalui Inovasi Bumdes, Ciamis: Jurnal Ilmiah Ilmu Pemerintahan

Mahbub Junaidi 2015, Evaluasi Pelaksanaan (BUMDES) Badan Usaha Milik Desa Berbasis Ekonomi Syariah Di Desa Timurejo Kecamatan Bangorejo Kabupaten Banyuwangi, Banyuwangi: Al-Iqtishadi

Noerma Alifahrani Bahtiar 2017, Partisipasi Masyarakat Dalam Pengawasan Program Alokasi Dana Desa (ADD) Di Desa Panjunan Kecamatan Sukodono Kabupaten Sidoarjo, Sidoarjo: Jurnal Kebijakan dan Manajemen Publik 
Rauf A. Hatu 2010, Pemberdayaan dan Pendampingan Sosial dalam Masyarakat (Suatu Kajian Teortis) Medan: Jurnal Inovasi

Valentine Queen Chintary dan Asih Widi Lestari 2016, Peran Pemerintah Desa Dalam Mengelola Badan Usaha Milik Desa (BUMDES), Malang: JISIP

Zulkarnain Ridlwan 2013, Payung Hukum Pembentukan BUMDes, Lampung: Fiat Justitia Jurnal Ilmu Hukum

Website:

BERDESA.COM,

PORTAL Kementerian Desa, Pembangunan Daerah Tertinggal Dan Transmigrasi Republik Indonesia 